\title{
PENINGKATAN EKONOMI DALAM PEMANFAATAN BUMDES MELALUI PELATIHAN PENYUSUNAN LAPORAN KEUANGAN BUMDES DI KECAMATAN BERINGIN KABUPATEN DELI SERDANG
}

\author{
Ahmad Muhajir ${ }^{1 *}$, Dimas Erlangga Kusuma ${ }^{2}$, Riza Fahlevi ${ }^{3}$ \\ ${ }^{1,2,3}$ Akuntansi, Fakultas Ekonomi, Universitas Al-Azhar, Jl. Pintu Air IV No.214, Kwala Bekala, Kec. \\ Medan Johor, Kota Medan, Sumatera Utara 20143 \\ *Amuhajir891@gmail.com
}

\begin{abstract}
ABSTRAK. Laporan keuangan merupakan catatan informasi keuangan suatu usaha/perusahaan pada suatu periode akuntansi yang dapat digunakan untuk menggambarkan kinerja perusahaan tersebut. Dilihat dari tujuannya yang digunakan untuk memenuhi kebutuhan bersama sebagian besar pemakai. Secara umum, prinsip pembukuan keuangan BUMDes tidak berbeda dengan pembukuan keuangan lembaga lain pada umumnya. BUMDes harus melakukan pencatatan atau pembukuan yang ditulis secara sistematis dari transaksi yang terjadi setiap hari. BUMDes harus melakukan pencatatan atau pembukuan yang tertulis secara sistematis dari transaksi yang terjadi setiap hari. Di Kecamatan Beringin para masyarakat beserta para perangkat desa serta pemerintah telah bersama-sama berusaha membentuk Badan Usaha Milik Desa (BUMDes) ini pada bulan september tahun 2015. Untuk itu dengan adanya Pengabdian yang diselenggarakan oleh Lembaga Penelitian dan pengabdian pada masyarakat (LPPM) serta belum lamanya dibentuk BUMDes ini sangatlah penting untuk bisa melatih masyarakat sekaligus para perangkat desa dalam membuat laporan keuangan secara sederhana, sehingga masalah-masalah yang timbul untuk 5 tahun kedepan dari suatu usaha sudah bisa diprediksi masalahmasalahyang akan dihadapi dengan mendapatkan pelatihan tentang pembuatan laporan keuangan secara sederhana.
\end{abstract}

Kata kunci: Ekonomi Kreatif, Pemanfaatan Bumdes, Penyusunan Laporan Keuangan Sederhana

ABSTRACT. Financial statements are records of financial information of a business/company in an accounting period that can be used to describe the performance of the company. Judging from the purpose used to meet the common needs of most users. In general, the principle of BUMDes financial bookkeeping is no different from the financial bookkeeping of other institutions in general. BUMDes must carry out systematic recording or bookkeeping of transactions that occur every day. BUMDes must carry out systematic written records or books of transactions that occur every day. In the Beringin District, the community and village officials and the government have jointly tried to form this Village-Owned Enterprise (BUMDes) in September 2015. For this reason, with the service organized by the Institute for Research and Community Service (LPPM) and has not The length of time that BUMDes was formed is very important to be able to train the community as well as village officials in making simple financial reports, so that problems that arise for the next 5 years from a business can be predicted. simple.

Keywords: Creative Economy, Utilization of Bumdes, Preparation of Simple Financial Statements

Terima 12 Januari 2022 Terima dan di revisi 15 Januari 2022 Disetujui 20 Januari 2022

\section{PENDAHULUAN}

Kecamatan Beringin adalah sebuah kecamatan yang merupakan ibu kota dari desa karang anyar, Kecamatan Beringin merupakan daerah Bandara Internasional Kuala Namu. Daerah Kecamatan Batang kuis. Adapun luas kecamatan beringin Luasnya 52,69 $\mathrm{Km} 2$ atau 5.269 Ha yang terdiri dari 11 Desa dan 89 Dusun dengan ibu kota desa karang anyar dengan titik koordinat 03,608662 lintang utara dan 098,88937 bujur timur. Keadaan alam Topografi kecamtan beringin daerah daataran rendah dengan ketinggian $1 \quad \mathrm{~s} / \mathrm{d} \quad 8$ meter permukaan laut. Iklim kecamatan beringin adalah sedang dengan dua musim yaitu musim hujan dan musim kemarau. Batas-batas kecamatan beringin adalah

-Sebelah utara: Kecamatan Pantai Labu 
-Sebelah Timur: Kecamatan Pagar Merbau dan Kabupaten Serdang Bedagai

-Sebelah Barat: Kecamtan Tanjung Morawa

-Sebelah Selatan: Kecamatan Lubuk Pakam

Jumlah Penduduk Kecamatan Beringin adalah saat ini 55.276 jiwa yang mendiami 13.056 rumah tangga yang terdiri dari suku bangsa dan agama. Mata pencaharian penduduk kecamatan beringin pada umumnya adalah Pertanian, secara Umumnya adalah : Pertanian, Buruh/Karyawan, Perdagangan, Nelayan, PNS/TNI/POLRI, Industri,dll. Adapun Nama-nama desa yang ada di kecamatan beringin adalah : Tumpatan, Psr VI Kuala Namu, Emplasmen Kuala Namu, Karang Anyar, Sidodadi Ramunia, Beringi,Psr V Kebun Kelapa, Sidoarjo II Ramunia, Arasa Kabu, Serdang, Sidourip Di Kecamatan Beringin sebagian mata pencaharian penduduknya yang paling utama adalah di bidang pertanian seperti Padi, jagung, kacang tanah, selain itu pula terdapat usaha kelompok seperti kerajinan topi, serta kelompok penjahit. Sehingga berdasarkan latar belakang tersebut adapun permasalahan dalam penulisan pengabdian ini adalah peningkatkan ekonomi dalam pemanfaatan BUMDes melalui pelatihan penyusunan laporan keuangan yang sederhana, yang artinya dengan semakin berkembang kegiatan ekonomi saat ini harus mampu menemukan inovasi dan kreativitas yang selalu baru melalui pemanfaatan badan usaha milik desa (BUMDes) ini dengan cara mentata kelola kembali dana-dana desa yang diperoleh dari masyarakat agar pemenuhan Modal Usaha BUMdes lebih jelas pengaturannya melalui penyusunan laporan keuangan yang sederhana. Laporan keuangan merupakan catatan informasi keuangan suatu usaha/perusahaan pada suatu periode akuntansi yang dapat digunakan untuk menggambarkan kinerja perusahaan tersebut. Dilihat dari tujuannya yang digunakan untuk memenuhi kebutuhan bersama sebagian besar pemakai, maka laporan keuangan secara karakteristiknya memiliki ciri-ciri sebagai berikut:

1. dapat dipahami-yang artinya dalam hal ini informasi yang disampaikan dapat dipahami dan istilah yang digunakan disesuaikan dengan pemahaman pemakai,

2. Relevan- dalam hal ini informasi yang disajikan di dalam laporan keuangan dapat mempengaruhi keputusan pengguna, sehingga isinya haruslah relevan,
3. Keandalan- dalam hal informasi yang disusun dalam laporan keuangan bebas dari pengertian yang menyesatkan dan kesalahan material,

4. dapat diperbandingkan - dalam hal ini laporan keuangan akan berguna apabila bisa dibandingkan dengan laporan keuangan periode sebelumnya. Secara umum, prinsip pembukuan keuangan BUMDes tidak berbeda dengan pembukuan keuangan lembaga lain pada umumnya. BUMDes harus melakukan pencatatan atau pembukuan yang ditulis secara sistematis dari transaksi yang terjadi setiap hari. BUMDes harus melakukan pencatatan atau pembukuan yang tertulis secara sistematis dari transaksi yang terjadi setiap hari.

Tujuan dari pembukuan keuangan secara umumnya adalah:

1. Untuk mengetahui perkembangan perusahaan dari waktu ke waktu, baik perkembangan penjualan, laba/rugi maupun struktur permodalan

2. Untuk mengetahui kemungkinan kerugian sejak dini, sehingga gulung tikar bisa dihindari

3. Untuk mengetahui kondisi persediaan barang/jasa setiap saat. Sehingga dapat digunakan untuk menyusun strategi manajemen persediaan.

4. Untuk mengetahui sumber dan penggunaan dana BUMDes, sehingga bisa mengevaluasi kinerja keuangan BUMDes.

Di Kecamatan Beringin para masyarakat beserta para perangkat desa serta pemerintah telah bersama-sama berusaha membentuk Badan Usaha Milik Desa (BUMDes) ini pada bulan september tahun 2015. Untuk itu dengan adanya Pengabdian yang diselenggarakan oleh Lembaga Penelitian dan pengabdian pada masyarakat (LPPM) serta belum lamanya dibentuk BUMDes ini sangatlah penting untuk bisa melatih masyarakat sekaligus para perangkat desa dalam membuat laporan keuangan secara sederhana, sehingga masalahmasalah yang timbul untuk 5 tahun kedepan dari suatu usaha sudah bisa diprediksi masalah-masalahyang akan dihadapi dengan mendapatkan pelatihan tentang pembuatan laporan keuangan secara sederhana. Untuk menyelesaian masalah-masalah diatas, maka perlu adanya pelatihan yang efisien dalam hal peningkatan ekonomi kreatif dalam pemanfaatan BUMDes melalui pelatihan 
penyusunan laporan keuangan secara sederhana ini dengan beberapa tahapan pembuatan sebagai berikut, dimana dalam pembuatan laporan keuangan BUMDes secara sederhana hanya 4 istilah akuntansi yang dipakai yaitu:

1. Harta yakni semua barang dan hak milik perusahaan (BUMDes) dan sumber ekonomi lainya itu harus tercatat, seperti harta tetap, harta lancar, dan harta tidak berwujud semua harus tercatat dalam laporan keuangan.

2. Hutang, dimana hutang ini merupakan kewajiban yang harus dibayar pada masa mendatang (sesuai dengan kesempatan yang dibuat) akibat dari suatu transaksi. Berdasarkan waktu pembayaran, hutang dibedakan menjadi hutang jangka pendek dan hutang jangka panjang.

3. Pendapatan, dimana pendapatan yang dimaksud adalah peningkatan harta/ aktiva perusahaan sebagai akibat terjadinya transaksi yang menguntungkan. Misalnya pembelian pupuk organik oleh para petani harga per kg Rp 50.000 kemudian dijual kembali ke pasar dengan harga per $\mathrm{Rp}$ 50.500., maka dengan keuntugan Rp 500 merupakan pendapatan BUMDes.

4. Biaya, dimana biaya merupakan adalah harta yang digunakan untuk menghasilkan pendapatan dalam satu periode tertentu yang habis dipakai, seperti Harga Pokok Penjualan (HPP), biaya operasi dan biaya lain-lain.

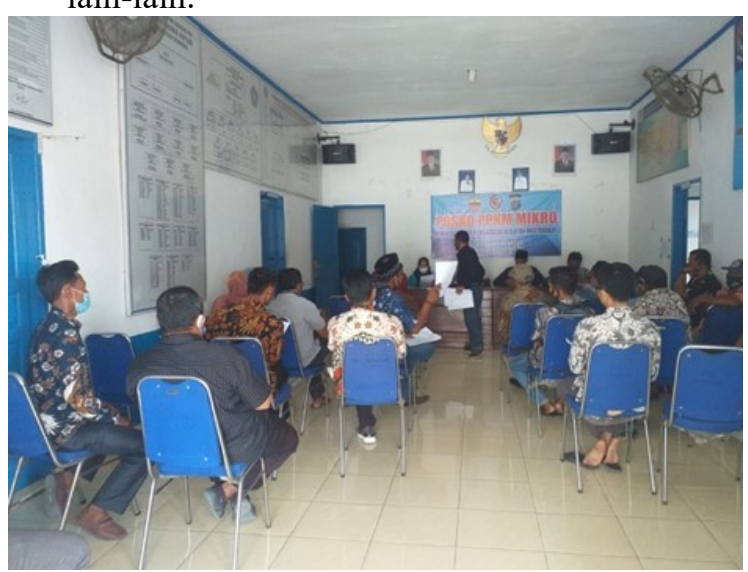

Gambar 1 aktivitas pelatihan

\section{METODE}

Adapun metode/konsep yang digunakan dalam menyelesaikan permasalahan ini yakni:
1. Pertama, dengan didampingi serta dilatih oleh instruktur yang sesuai dengan bidang keahlian yakni di bidang manajemen keuangan atau akuntansi untuk melatih Pengurus BUMDES khususnya bendahara yang mengelola badan usaha milik desa ini.

2. Kedua, dalam pembuatan laporan keuangan sederhana instruktur yang ahli dibidangnya melatih cara pembuatan laporan keuangan kepada Pengurus BUMDES apa itu tentang neraca atau laporan laba rugi.

3. Ketiga, dalam laporan keuangan neraca ada yang namanya sisi aktiva dan sisi pasiva, dimana dalam sisi aktiva itu menyangkut tentang harta tetap, harta lancar, dan harta tidak berwujud. Dalam harta tetap itu menyangkut tanah/lahan dan bangunan, mesin dan berbagai peralatan lain, kendaraan, perabotan kantor, inventaris gudang, inventaris kantor serta prasarana lainnya. kemudian harta lancar adalah semua harta yang diharapkan dapat dicairkan tidak lebih dari satu tahun siklus akuntansi, seperti: kas,persediaan barang, piutang, piutang wesel, investasi jangka pendek, perlengkapan serta beban yang dibayar dimuka. Selanjutnya harta tidak berwujud yang merupakan tidak memiliki wujud fisik secara nyata serta dimiliki guna menghasilkan barang atau jasa, disewakan maupun hanya untuk tujuan administrasi, aktiva tidak berwujud ini diakui sebesar harga perolehan, seperti : hak sewa, hak paten, merek dagamg, penggandaan, perizinan, franchise dll. Kemudian pada sisi pasiva terdapat hutang jangka pendek dan hutang jangka panjang. Hutang jangka pendek merupakan hutang yang jangka waktunya kurang dari satu tahun seperti utang dagang, utang wesel, hutang deviden, pendapatan dibayar dimuka, utang jangka panjang yang telah jatuh tempo, pajak penjualan, utang gaji, kewajiban kontingensi (kondisi yang tidak pasti yang mungkin terjadi dimasa yang akan datang. Selanjutnya hutang jangka panjang merupakan kewajiban kepada pihak tertentu yang harus dilunasi dalam jangka waktu lebih dari satu tahun atau satu periode akuntansi. Seperti: bond/obligasi, utang wesel jangka panjang, hutang hipotek (yakni penyerahan tertulis mengenai hak atas 
harta benda tak bergerak untuk menjamin pembayaran hutang dengan ketentuan bahwa penyerahan itu akan dibatalkan setelelah waktu pembayaran. Hutang hipotik ini bisa diangsur dan lain-lain

4. Keempat, dalam laporan keuangan sederhana dalam bentuk laporan rugi/laba dimana dalam laporan ini terdapat unsur pendapatan dan unsur biaya, pendapatan terdiri dari pendapatan operational dan non operational, pendapatan operational antara lain: penjualan (sales) dimana penjualan ini terbagi menjadi dua ada penjualan bruto dan penjualan netto, selanjutnya, potongan pembelian tunai dan penerimaan tambahan dari pembelian. Kemudian contoh dari pendapatan non operational sebagai berikut: penghasilan bunga, penghasilan sewa, penghasilan dividen kas, dan profit. Selanjutnya unsur biaya dalam laporan rugi/laba seperti: penggolangan biaya menurut obyek pengeluaran contoh: biaya gajidan upah, biaya soda, biaya depresiasi mesin, biaya asuransi, biaya bunga, biaya pupuk dll. Penggolongan biaya menurut fungsi pokok perusahaan contoh: biaya produksi, biaya bahan mentah tidak langsung (bahan penolong), biaya reparasi dan pemeliharaan, biaya yang timbul sebagai akibat penilaian terhadap aktiva tetap, biaya yang timbul sebagai akibat berlalunya waktu, biaya overhead pabrik lain yang secara langsung memerlukan peengeluaran uang tunai, biaya pemasaran, serta biaya administrasi dan umum. Selajutnya penggolongan biaya dengan sesuatu yang dibiayai contoh biaya langsung serta biaya tidak langsung. Penggolongan biaya menurut perilakunya dalan hubungan perubahan volume kegiatan contoh biaya variabel seperti biaya bahan baku, biaya tenaga kerja langsung, biaya semivariabel seperti biaya tetap biaya variabel, serta biaya semifixed. Penggolongan biaya atas dasar jangka waktu manfaatnya contoh pengeluaran modal serta pengeluaran pendapatan.

Dari langkah-langkah tersebut diatas masyarakat serta pengurus BUMDES yang diberi pelatihan dalam pembuatan laporan keuangan sederhana ini harus memahami dahulu setiap pos-pos yang ada dalam neraca dan laporan rugi/laba yang biasa dipakai dalam pembukuan BUMDes, karena dengan memahami pos-pos tersebut masalah-masalah seperti kerugian sejak dini, perkembagan perusahaan dari waktu ke waktu, serta sumber dan pengunaan dana dari BUMDes bisa diproteksi semenjak dini karena siklus perkembangan dari sebuah usaha pasti akan mengalami pasang surut karena kebanyakan dari masyarakat umum yang baru memulai sebuah usaha mengalami permasalahan dalam pembukuan, padahal pembukuan dalam suatu usaha itu sangatlah penting dalam hal perputaran modal kerja sebuah usaha. Adapun yang menjadi mitra dalam pelaksanaan pengabdian Badan Usaha Milik Desa yang terdapat di Kecamatan Beringin Kabupaten Deliserdang.

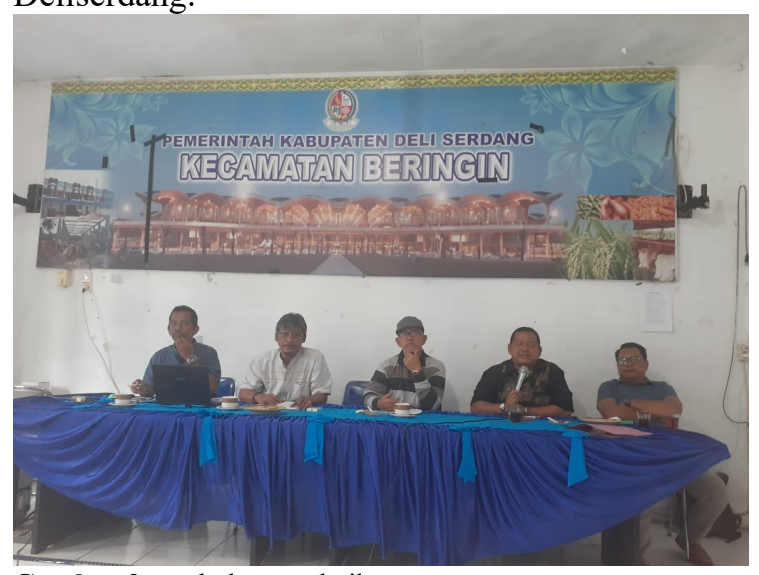

Gambar 2 pembukaan pelatihan

\section{HASIL DAN PEMBAHASAN}

Pengabdian kepada masyarakat ini secara keseluruhan bertujuan untuk meningkatkan kualitas pengelolaan keuangan dan memaksimalkan potensi serta peran BUMDes di Kecamatan Beringin baik secara institusional kepada Desa maupun secara komunal kepada masyarakat secara luas. Sebagai lembaga berorientasi profit yang dimiliki oleh Desa, keberadaan BUMDes diharapkan tidak sekedar mampu mendukung desa dari keuntungan yang diperolehnya tetapi juga diharapkan mampu menggiatkan peran serta masyarakat dalam mengelola perekonomian desa secara mandiri melalui BUMDes sebagai motor dan akselarator. Harapan tersebut dapat diwujudkan dengan terlebih dahulu dilakukan perbaikan atau optimalisasi tata kelola BUMDes di Kecamatan Beringin. Merujuk pada tujuan awal kegiatan pengabdian kepada masyarakat 
ini, maka pendampingan pengalolaan keuangan BUMDes terlebih dahulu dilakukan melalui tahapan identifikasi tata kelola BUMDes Tata kelola merupakan serangkaian struktur dan fungsi serta sistem dan proses yang telah ditetapkan untuk memastikan ketercapaian tujuan yang telah ditentukan sebelumnya oleh suatu organisasi. Tata kelola mencakup aspek Struktural, Finansial, dan Sosial.

Tata Kelola Struktural

Kecamatan Beringin Kabupaten Deliserdang terdiri dari 11 Desa dan sudah memiliki 7 Badan Usaha Miliki Desa atau BumDes. Ratarata BUMDes di kecamatan beringin berdiri pada tahun 2015 hingga 2018. Adapun namanama BUMDes di Kecamatan Beringin Kabupaten Deliserdang antara lain :

Kecamatan Desa Nama Bumdes

Beringin Karang Anyar Karya Bakti

$$
\begin{array}{lll}
\text { Sidourip } & \text { Jaya Gemilang } & \\
\text { Beringin } & \text { Beringin } & \text { Maju }
\end{array}
$$

Bersama

$\begin{array}{ll}\text { Sidoarjo II Ramunia } & \text { Marsada } \\ \text { Sidodadi Ramunia } & \text { Sejahtera } \\ \text { Pasar V Kebun Kelapa } & \text { Palapa } \\ \text { Aras Kabu } & \text { Aras Kabu Jaya }\end{array}$

Jenis usaha yang dikembangkan adalah jasa keuangan dan perdagangan, Grosir, Depot Air Minum dan Jasa Pertanian. Dari segi legalitasnya, BUMDes di Kecamatan Beringin Kabupaten Deliserdang didirikan berdasarkan Peraturan Desa (Perdes) yang ditetapkan setelah pelaksanaan Musyawarah Desa pembentukan pengurus BUMDes. Kelengkapan organisasi BUMDes tertuang dalam Perdes tersebut mencakup aspek Anggaran Dasar di Bab III dan Anggaran Rumah Tangga tertuang di BAB IV. Adapun dari segi administrasi, BUMDes di Kecamatan Beringin Kabupaten Deliserdang telah melengkapi identitas organisasi berupa struktur organisasi yang telah terpasang dan juga papan nama BUMDes terpasang di halaman kantor. Sebagai ruang administrasi dan operasional, BUMdes di Kecamatan Beringin ini diberikan ruang dikantor Desa atau diberinkan ruang tersendiri diluar kantor Desa dengan status pinjam. BUMDes di Kecamatan Beringin ini juga telah membuat tugas pokok dan fungsi (tupoksi) dari setiap perangkat pengurus. Struktur kepengurusan

\begin{tabular}{|c|c|c|c|c|c|}
\hline \multirow[t]{2}{*}{ Desa } & \multirow{2}{*}{$\begin{array}{l}\text { Nama } \\
\text { Bumdes }\end{array}$} & \multicolumn{4}{|c|}{ Penyertaan Modal Dana Desa } \\
\hline & & TA 2016 & TA $2017 \quad$ TA 2018 & TA 2019 & TA 2020 \\
\hline \multicolumn{6}{|c|}{$\mathbf{8 1} \mid \mathrm{P}$ a g e } \\
\hline
\end{tabular}
BUMDes BM secara garis besar telah sesuai dengan ketentuan Permendes No 4 tahun 2015 tentang Pendirian, Pengurusan dan Pengelolaan, dan Pembubaran Badan Usaha Milik Desa.

BUMDes di semua Kecamatan Beringin Kabupaten Deliserdang telah memiliki struktur pengawas, direktur/ketua, sekretaris dan bendahara serta karyawan. Untuk posisi penasehat dinamakan Pembina. Perbedaan penamaan tersebut tidak memiliki perbedaan secara substansial. Selain itu, BUMDes di Kecamatan Beringin Kabupaten Deliserdang juga memiliki struktur kepala unit sebagai koordinator penyelenggaraan kegiatan usaha. Secara kelembagaan, BUMDes di Kecamatan Beringin Kabupaten Deliserdang telah melengkapi struktur dan fungsi organisasi dengan cukup baik. Hal ini tampak dari kelengkapan tupoksi yang telah dipersiapkan secara baik. Aspek cakupan struktur yang diwajibkan oleh Permendes 4/2015 telah tercantum di dalam organisasi. Selain itu, juga ditambahkan struktur dan fungsi kepala unit dan karyawan. Kelengkapan struktur dan fungsi merupakan aspek vital untuk dapat menjalankan suatu organisasi secara baik, disamping juga mengantisipasi perkembangan mendatang atas kondisi lingkungan maupun tumbuh dan berkembangnya organisasi. Hanya saja, secara nyata jumlah Sumber Daya Manusia (SDM) yang terlibat dalam struktur BUMDes masih sangat kurang, Keberadaan jumlah SDM tentu berperan penting terhadap berjalannya suatu organisasi karena unsur pelaku merupakan subyek penting berjalannya secara serius kebutuhan pokok penambahan jumlah SDM di BUMDes ini agar dapat berfungsi secara maksimal

Tinjauan Kinerja Keuangan

Ditinjau dari aspek kinerja keuangan, terdapat beberapa indikator yang menunjukkan tingkat perkembangan BUMDes di Kecamatan Beringin Kabupaten Deliserdang yang semakin baik. Permodalan BUMDes diperoleh dari APBN Melalui Dana Desa di tahun 2015 dan sampai tahun 2021. Berikut adalah rincian perolehan permodalan di Kecamatan Beringin Kabupaten Deliserdang entitas tersebut. Pihak Desa perlu memikirkan 


\begin{tabular}{|c|c|c|c|c|c|c|}
\hline $\begin{array}{l}\text { Karang } \\
\text { Anyar }\end{array}$ & Karya Bakti & 11.120 .000 & & - & 95.000 .000 & - \\
\hline Sidourip & $\begin{array}{l}\text { Jaya } \\
\text { Gemilang }\end{array}$ & 20.000 .000 & 62.457 .000 & - & 20.000 .000 & - \\
\hline Beringin & $\begin{array}{l}\text { Beringin } \\
\text { Maju } \\
\text { Bersama }\end{array}$ & - & 174.300 .000 & - & - & - \\
\hline $\begin{array}{l}\text { Sidoarjo } \\
\text { II } \\
\text { Ramunia }\end{array}$ & Marsada & - & 150.000 .000 & - & - & - \\
\hline $\begin{array}{l}\text { Sidodadi } \\
\text { Ramunia }\end{array}$ & Sejahtera & - & 100.000 .000 & - & - & - \\
\hline $\begin{array}{l}\text { Pasar V } \\
\text { Kebun } \\
\text { Kelapa }\end{array}$ & Palapa & - & 117.000 .000 & 80.000 .000 & - & - \\
\hline Aras Kabu & $\begin{array}{ll}\text { Aras } & \text { Kabu } \\
\text { Jaya } & \end{array}$ & - & 150.000 .000 & 50.000 .000 & - & - \\
\hline
\end{tabular}

Dari permodalan yang dimiliki oleh BUMDes

di Kecamatan Beringin Kabupaten Deliserdang, terdapat perkembangan sebesar $32 \%$. Dalam masa waktu sekitar 5 tahun kenaikan tersebut menunjukkan kinerja keuangan yang cukup baik. Di sisi lain rasio efisiensi penggunaan aset ditaksir sebesar $5,95 \%$. Hal ini menunjukkan pemanfaatan aset yang digunakan dengan optimal.

\section{Aspek Sosial}

Salah satu aspek dari tata kelola BUMDes yang penting adalah dampak dan atau partisipasi masyarakat dalam pengelolaan atau manfaat yang diperoleh secara tidak langsung. Meskipun BUMDes merupakan salah satu unit bisnis yang diselenggarakan oleh Desa yang berorientasi profit, tidak menutup kewajiban untuk melibatkan atau mempertimbangkan dampak terhadap masyarakat atau sosial. Meskipun tidak dipersyaratkan atau menjadi aturan secara eksplisit di Permendes terkait BUMDes, pihak Desa Se-Kecamatan Beringin Kabupaten Delisedang telah melakukan identifikasi dampak sosial keberadaan BUMDes

\section{Transparansi dan Partisipasi.}

Keberadaan BUMDes sebagai salah satu instrumen bisnis di Pemerintah Desa tidak bisa dilepaskan dari aspek politik dan kemasyarakatan. Aspek politik pada bidang bisnis tersebut tampak dari indikator transparansi dan partisipasi masyarakat baik dalam pemanfaatan modal, menabung ataupun pemanfaatan layanan dan jasa yang diberikan oleh BUMDes. Masyarakat telah dapat memanfaatkan modal pinjaman yang diberikan baik untuk tujuan konsumsi maupun produksi.
Dari rasio perbandingan antara pinjaman konsumtif dan produktif tampak lebih banyak digunakan untuk tujuan produktif. Masyarakat juga dapat memanfaatkan jasa keuangan berupa tabungan yang disediakan untuk menyimpan kelebihan dana mereka. Selain itu, masyarakat juga dapat memanfaatkan jasa fotokopi, pembelian pupuk, dan pakan ternak bagi mereka yang membutuhkan,

\section{Pemberdayaan}

Keberadaan BUMDes juga berperan untuk memberdayakan masyarakat sekitar. Dua jenis pemberdayaan utama yang diberikan adalah penyediaan permodalan dan juga penjualan produk UKM. Penyediaan permodalan Memberikan pelayan permodalan bagi masyarakat yang membutuhkan tambahan modal untuk usaha baik sektor Pertanian, Industri Kecil, Perdagangan, Jasa maupun Investasi. Adapun penjualan produk UKM dapat membantu Membantu menjualkan produk UKM yang ada diwilayah Desa SeKecamatan Beringin dan sekitarnya

\section{SIMPULAN}

Badan Usaha Milik Desa (BUMDes) di Kecamatan Beringin Kabupaten Deliserdang memiliki usaha utama jasa keuangan dan usaha pendukung berupa perdagangan, Pakan Ternak, alat tulis kantor. Aspek legalitas dan kelembagaan struktural telah dipersiapkan dengan baik oleh Kepala Desa dalam membangun dasar utama organisasi. Struktur dan fungsi yang ada juga telah sesuai dengan ketentuan Permendes 4 tahun 2015. Disamping itu, aspek keuangan juga menunjukkan adanya kemajuan dan indikator kinerja yang baik, 
selain permodalan yang mencukupi. Pihak manajemen juga telah mampu memanfaatkan sumber daya eksternal dalam mendukung program dan kegiatan BUMDes. Dampak ekonomi telah dirasakan oleh masyarakat. Selain itu, BUMDes juga turut berkontribusi terhadap Pendapatan Asli Desa secara optimal. Aspek sosial juga turut dirasakan oleh masyarakat sekitar seiring dengan keberadaan BUMDes. Keterlibatan, partisipasi, dan transparansi masyarakat terhadap BUMDes ditnjukkan dengan pemberdayaan dan menguatnya jejaring dan mitra BUMDes berdampak pada masyarakat secara luas

Keberadaan BUMDes di Kecamatan Beringin Kabupaten Deliserdang masih memiliki keterbatasan personalia (SDM) yang mencukupi untuk dapat menjalankan proses bisnis dengan optimal. Perlu adanya keterlibatan secara aktif dari perangkat Desa untuk mengatasi kekurangan SDM tersebut. Selain itu, bisnis jasa keuangan dirasa tidak bisa optimal memberdayakan potensi ekonomi masyarakat. Perlu adanya langkah-langkah inovatif dan kreatif untuk mendorong pengembangan bisnis yang berorientasi pada sektor riil atau mendorong sektor perekonomian utama di tengah-tengah masyarakat seperti bidang pertanian, perkebunan maupun perikanan.

\section{UCAPAN TERIMAKASIH}

Dengan selesaikan pengabdian terhadap masyarakat ini di ucapkan banyak terima kasih kepada Kecamatan Beringin Kabupaten Deli Serdang

\section{DAFTAR PUSTAKA}

Peraturan Menteri Desa, Pembangunan Daerah Tertinggal, dan Transmigrasi Republik Indonesia No 4 Tahun 2015 tentang Pendirian, Pengurusan dan Pengelolaan, dan Pembubaran Badan Usaha Milik Desa

Suryanto, Rudy. 2018. Peta Jalan Bumdes Indonesia Menuju Kemandirian Ekonomi Desa. Makalah disampaikan pada Seminar Ekonomi Kerakyatan Pusat Studi Ekonomi Rakyat, Fakultas Ekonomika dan Bisnis UGM

Hanafi, mamduh (2009), Analisis Laporan Keuangan, Edisi Keempat, Penerbit UPP 